\title{
Presence of DNA Fragmentation and Lack of Neuroprotective Effect in DFF45 Knockout Mice Subjected to Traumatic Brain Injury
}

\author{
Alexander G. Yakovlev, ${ }^{1}$ Xiao Di, ${ }^{1}$ Vilen Movsesyan, ${ }^{1}$ Paul G.M. Mullins, ${ }^{1}$ Geping Wang, ${ }^{1}$ Hamid \\ Boulares, ${ }^{2}$ Jianhua Zhang, ${ }^{3}$ Ming $\mathrm{Xu}^{3}$ and Alan I. Faden ${ }^{1}$ \\ ${ }^{1}$ Department of Neuroscience, Georgetown University, Washington, DC, USA \\ ${ }^{2}$ Department of Biochemistry and Molecular Biology, Georgetown University, Washington, DC, USA \\ ${ }^{3}$ Department of Cell Biology, Neurobiology, and Anatomy, University of Cincinnati College of Medicine, \\ Cincinnati, Ohio, USA
}

Accepted November 3, 2000

\begin{abstract}
Background: Apoptosis plays an important pathophysiologic role in neuronal cell loss and associated neurologic deficits following traumatic brain injury (TBI). DNA fragmentation represents one of the characteristic biochemical features of neuronal apoptosis and is observed after experimental TBI. DFF45 and DFF40 are essential for DNA fragmentation in various models of apoptosis.

Materials and Methods: We used mice deficient in DFF45 and wild-type controls. Oligonucleosomal DNA fragmentation induced by TBI was analyzed using in vivo and in vitro assays. Expression and integrity of DFF45 and DFF40 proteins was assessed by Western analysis. Other outcome measurements included neurologic scoring, learning/memory tests, lesion volume measurements (MRI), and assessment of cell viability in vitro among others.

Results: We compared the effects of controlled cortical impact (CCI) trauma in DFF45 knockout mice and wild-type controls. Analysis of TBI-induced DNA fragmentation in brain cortex from wild-type and DFF45 knockout mice indicates that, although somewhat delayed, oligonucleoso-
\end{abstract}

mal cleavage of DNA occurs after TBI in DFF45 knockout mice. DFF45 knockouts showed no significant differences in behavioral outcomes or lesion volumes after TBI as compared to wild-type controls. Using an in vitro reconstitution system, we also demonstrated that cleavage of DFF45 by caspase-3 is not sufficient for DNA fragmentation induced by protein extracts from rat brain cortex. We found that endonuclease activity induced in rat brain cortex following TBI depends on the presence of $\mathrm{Mg}^{2+}$ and $\mathrm{Ca}^{2+}$, but is not inhibited by $\mathrm{Zn}^{2+}$. Primary neuronal cultures from DFF45 knockouts failed to show DNA laddering in response to staurosporine, but did show prominent, albeit delayed, DNA fragmentation following treatment with etoposide. In contrast, primary neurons from wildtype animals demonstrated marked DNA fragmentation following treatment with staurosporine or etoposide.

Conclusions: The results of this study suggest that, in addition to DFF45/40, other endonucleases may be essential for chromatin degradation during neuronal apoptosis in adult brain after TBI.

\section{Introduction}

Apoptosis plays an important role in delayed neuronal loss following traumatic brain injury (TBI) or cerebral ischemia (1-4). Such cell death is characterized by specific morphologic and biochemical features; the latter include the activation of caspases and a subsequent cleavage of a variety of substrates including structural proteins, DNA repair enzymes, and endonuclease inhibitors (5). Internucleosomal DNA fragmentation, resulting from activation of endonucleases, represents one of the characteristic biochemical features of apoptosis in a variety of

Address correspondence and reprint requests to: A.I. Faden, MD, Department of Neuroscience, Georgetown University, Research Building, Room EP12, 3970 Reservoir Road NW, Washington, DC 20007, USA. Telephone: 202-687-0492; Fax: 202-687-0617; E-mail: fadena@giccs.georgetown.edu experimental models, including TBI $(4,6,7)$. Potential endonucleases that participate in apoptosis include the caspase-activated enzymes (CAD) (8-10) and NUC70 (11), divalent cation-dependent neutral $(12,13)$ or acidic (14) endonucleases, leukemiaassociated endo-exonucleases (15), and $\mathrm{Ca}^{2+}$ - and $\mathrm{Mg}^{2+}$-dependent endonucleases (CMEs) (16-19).

CAD, also known as DNA fragmentation factor (DFF40), is a $40-\mathrm{kDa}$ protein that is translated in the presence of its inhibitor (ICAD, or DFF45), which functions as a specific chaperone and forms heterodimer with DFF40 in proliferating cells $(20,21)$. In vitro studies have shown that DFF45 is cleaved by caspase-3, releasing the nuclease activity of DFF40 from inhibitory control and triggering DNA fragmentation (22-27). Recent studies indicate that DFF45 may be essential in various models of apoptosis. Thus, primary thymocytes from DFF45deficient mice are resistant to apoptosis following 
exposure to several apoptotic stimuli (28). After TBI, caspase- 3 is activated $(4,29,30)$ and DFF45 is cleaved (31). Consequently, DFF proteins may undergo translocation to cell nucleus and initiate apoptotic DNA degradation postinjury.

Using a combination of in vivo and in vitro techniques, we have previously investigated neuronal apoptosis caused by fluid percussion-induced TBI in rats (4). We demonstrated caspase-3-dependent internucleosomal cleavage of genomic DNA in neurons from injured cortex and hippocampus after injury. In the present study, we examined a potential role for DFF40 and DFF45 in TBI-induced DNA fragmentation and associated neuronal apoptosis in mice, by comparing effects in DFF45 knockout mice and wild-type controls. Neuronal cell culture models and reconstitution of apoptosis in vitro were also used to address this issue. The results indicate that, although somewhat delayed, oligonucleosomal cleavage of DNA occurs after CCI injury in DFF45 knockout mice and that such animals show no significant differences in behavioral outcomes or lesion volumes as compared to wild-type controls. Ex vivo and in vitro experiments supported these in vivo results. From these observations, we suggest that in addition to DFF45/40 other endonucleases may be essential in certain models of neuronal apoptosis.

\section{Materials and Methods \\ Rat Fluid Percussion Brain Trauma Model}

This model, initially modified from those previously utilized by us and other investigators in rats, is highly reproducible and has been extensively characterized with regard to its biochemical, physiologic, morphologic, and behavioral correlates (32). Briefly, male Sprague-Dawley rats $(400 \pm 25 \mathrm{~g} \mathrm{bw})$ were anesthetized with sodium pentobarbital $(60 \mathrm{mg} / \mathrm{kg} \mathrm{ip})$, intubated, and implanted with femoral venous and arterial catheters. Brain temperature was assessed indirectly through a thermister in the temporalis muscle and body temperature maintained through a feedback-controlled heating blanket. Blood pressure is continuously monitored, and arterial blood gases were analyzed periodically. A small craniotomy $(2 \mathrm{~mm})$, located midway between the lambda and bregma sutures over the left parietal cortex allowed insertion of a Leur-Loc that is cemented in place. The fluid-percussion head injury device, manufactured by the Medical College of Virginia, consists of a plexiglass cylindrical reservoir filled with $37^{\circ} \mathrm{C}$ isotonic saline; one end includes a transducer that is mounted and connected to a $5-\mathrm{mm}$ tube that attaches through a male Leur-Loc fitting to the female Leur-Loc cemented at the time of surgery. A pendulum strikes a piston at the opposite end of the device, producing a pressure pulse of approximately 22 msec duration, leading to the deformation of underlying brain. The degree of injury is related to the pressure pulse expressed in atmospheres (atm) -a pulse of $2.4 \pm 0.1$ atm produces a moderately severe injury that permits evaluation of pharmacologic interventions. Animals were maintained on anesthetics (sodium pentobarbital, $15 \mathrm{mg} / \mathrm{kg} / \mathrm{hr}$ ) and artificially ventilated.

\section{Mouse Brain Trauma Model}

DFF45 knockout mice have been described in the previous report (33). The genetic background of all the mice used was C57BL/6Jx129Sv. Moreover, all the mice used in the present studies were produced from littermates from the same family. Genotypes of the mice were confirmed by Southern blot hybridization. DFF45 knockouts or wild-type controls were subjected to controlled cortical impact brain injury previously detailed $(34,35)$. The injury device consists of a microprocessor-controlled pneumatic impactor with an interchangeable tip. The impactor is vertically mounted on a mill table that allows for precise adjustment in the vertical plane above the mouse head, which itself is secured in a stereotaxic apparatus. The core rod of a linear variable differential transducer (LVDT) is attached to the lower end of the impactor to allow measurement of velocities between 3.0 and $9.0 \mathrm{~m} / \mathrm{sec}$. Velocity of the impactor is controlled by fine tuning both positive and negative (back) air pressures. An oscilloscope records the time/displacement curve produced by the downward force on the LVDT, allowing precise measurement of the impactor velocity. Surgical anesthesia was induced and maintained in freely breathing mice $(20-25 \mathrm{~g})$ with $4 \%$ and $2 \%$ isoflurane, using a flow rate of $1-1.5 \mathrm{l} / \mathrm{min}$ oxygen. Depth of anesthesia was assessed by the palpebral and pedalwithdrawal reflexes, in addition to monitoring of the respiration rate of the mouse. The animal was placed onto a heated pad, with core body temperature monitored via a rectal probe and maintained at $38 \pm 0.2^{\circ} \mathrm{C}$. The head was mounted in the stereotaxic frame of the device and a $4-\mathrm{mm}$ craniotomy was made on the central aspect of the left parietal bone with a tissue puncher. The impounder tip of the pneumatic injury device was positioned to the surface of the exposed dura and then withdrawn the 44-mm stroke distance. The impactor velocity, deformation depth, and area of injury were set and the brain was impacted. Each mouse was then placed in a heated cage for $30 \mathrm{~min}$ following recovery from the anesthetic.

All animal experiments in this study were in compliance with Georgetown University Animal Care and Use Committee guidelines and the PHS "Guide for the Care and Use of Laboratory Animals" NIH Publication No. 85-23.

\section{Neurologic Scoring}

Chronic neurologic recovery was examined in mice using a test of motor function. Fine motor coordination was evaluated using a beam walking task (35). 
A narrow wooden beam $(6 \mathrm{~mm}$ wide and $120 \mathrm{~mm}$ long) was suspended $300 \mathrm{~mm}$ above a $60-\mathrm{mm}$ thick foam rubber pad. The mouse was placed on one end of the beam and the number of footfaults for the right hindlimb recorded over 50 steps counted in either direction on the beam. A basal level of competence at this task was established before surgery, with an acceptance level of $<10$ faults per 50 steps, to ensure similar levels of performance between knockout and wild-type animals prior to injury.

\section{Learning/Memory Tests (Morris Water Maze, Barnes Maze)}

Learning and memory deficits in mice were detected using a water maze paradigm similar to that originally described by Morris $(34,36)$. Briefly, all mice were introduced and maintained in the test environment for 7 days prior to the commencement of studies. Spatial learning was assessed by training the animals to locate a hidden, submerged platform using extramaze visual information. The apparatus used consisted of a large, white circular pool $(90 \mathrm{~cm}$ diameter, water temperature $24 \pm 1^{\circ} \mathrm{C}$ ) with a plexiglass platform (76 mm diameter) painted white and submerged $(15 \mathrm{~mm})$ below the surface of the water, which had been rendered opaque with the addition of dilute, white, nontoxic paint. During training, the platform was hidden in one quadrant and the animal was gently placed into the water facing the wall at one of four randomly chosen locations separated by 90 degrees. The latency to find the hidden platform within a 90 -sec criterion time was recorded by a blinded observer. Animals were allowed to remain on the platform for $15 \mathrm{sec}$ on the first trial and $10 \mathrm{sec}$ on all subsequent trials. There was an intertrial interval of $30 \mathrm{~min}$, during which time the animals were towel dried and placed under a heat lamp. A series of 16 training trials administered in blocks of 4 were conducted on days $14,15,16$, and 17 posttraining (after TBI). At 4 days following the last training trial, the mice were tested for memory retention using a single probe trial in which the platform was removed from the maze and the animals were given $90 \mathrm{sec}$ to swim while a computerassisted video tracking device (Chromotrack 4.02) recorded their swim path. To control for visual discriminative ability or motor impairment, both of which may adversely affect outcome in the water maze, the same animals were finally required to locate a clearly visible black platform (placed in a different location) raised $5 \mathrm{~mm}$ above the water surface. Spatial working memory was assessed on days 21-23 postsurgery using a procedure described in our previous study (34). Each mouse received four pairs of trials per day. During testing, the animal was placed into the water at one of four start positions (N, S, E, W) and allowed to locate the hidden platform, which was at one of four possible positions. Both the starting position and platform placement were selected for each of the trials.

\section{Lesion Volume Measurements Using MRI}

At 21 days after CCI mice were anesthetized using sodium pentobarbital (70 $\mathrm{mg} / \mathrm{kg}$ ip) and subjected to MRI in a Bruker 7T/21 cm Biospec-Avance system (Bruker, Ettingen, Germany). Briefly, animals were placed within a plexiglass animal bed with a heating pad warmed to $37^{\circ} \mathrm{C}$ to maintain the animal's temperature. Respiratory gating to reduce motion artifacts was achieved using a homemade respiratory monitor as described previously (37). The animal bed was positioned so the mouse head was in the center of the magnet within a $72-\mathrm{mm}{ }^{1} \mathrm{H}$ birdcage resonator (Bruker). Field homogeneity across the brain was optimized and a sagittal scout image acquired (RARE image, FOV $=3 \times 3 \mathrm{~cm}, 128 \times 128$ resolution, TR/TE $=1500 / 10 \mathrm{msec}$ with a rare factor of 8 making the effective TE $=40 \mathrm{msec}$ ). Multi-slice T2-weighted images were then acquired to obtain eight contiguous slices commencing at the end of the olfactory bulb and working caudally $(\mathrm{FOV}=2.5 \times$ $2.5 \mathrm{~cm}$, slice thickness $=1 \mathrm{~mm}, 128 \times 128$ resolution, TR/TE $=1500 / 20 \mathrm{msec}, 4$ echo images, and 2 averages). Each scan took approximately $8 \mathrm{~min}$ and injured tissue volume was estimated from the summation of areas of hyperintensity on each slice, multiplied by slice thickness, for both the ipsilateral and contralateral hemispheres.

Similar methods have been used to measure lesion volumes after TBI in humans (38) as well as after cerebral ischemia in rats (39). We have found that such MRI lesion volume measurements correlate significantly with histologic lesion volume measurements using stereology (in preparation).

\section{Tissue Cultures}

Cortical neuronal cultures were derived from mouse embryonic cortices. Briefly, cortices from 15-16 days old embryos were cleaned from their meninges and blood vessels in Krebs-Ringers bicarbonate buffer containing $0.3 \%$ bovine serum albumin (BSA, Life Technologies, Rockville, MD, USA). Cortices were then minced and dissociated in the same buffer with $1800 \mathrm{U} / \mathrm{ml}$ trypsin (Sigma, St. Louis, MO, USA) at $37^{\circ} \mathrm{C}$ for $20 \mathrm{~min}$. Following the addition of $200 \mathrm{U} / \mathrm{ml}$ DNase I (Sigma) and $3600 \mathrm{U} / \mathrm{ml}$ soybean trypsin inhibitor (Sigma) to the suspension, cells were triturated through a $5-\mathrm{ml}$ pipet. After the tissue was allowed to settle for 5-10 min, the supernatant was collected, and the remaining tissue pellet was retriturated. The combined supernatants were then centrifuged through a $4 \%$ BSA layer and the cell pellet was resuspended in neuronal seeding medium (NSM), which consisted of neurobasal medium (Gibco) supplemented with $1.1 \% 100 \times$ antibioticantimycotic solution Rockville, MD, USA (Biofluids, Rockville, MD, USA), $25 \mu \mathrm{M}$ Na-glutamate, $0.5 \mathrm{mM}$ L-glutamine, and 2\% B27 supplement (Gibco). Cells were seeded at a density of $5 \times 10^{5}$ cells $/ \mathrm{ml}$ onto polyD-lysine (70-150 kD, Sigma) coated 96-well plates (Corning, Corning, NY, USA) or 60-mm Petri dishes 
(Beckton Dickinson, Labware, Franklin Lakes, NJ, USA). All experiments were performed on cultures at 3 day in vitro. Cell death was induced in cultured neurons by incubation with $0.5 \mu \mathrm{M}$ staurosporine or $50 \mu \mathrm{M}$ etoposide.

For preparations of mouse splenocytes and thymocytes, spleens or thymi were aseptically removed and washed with phosphate-buffered saline (PBS). Tissue was passed through a wire screen to produce a single cell suspension in RPMI 1640. The spleen suspension was then placed over Ficoll-Paque Plus (Amersham Pharmacia, Piscataway, NJ, USA) and centrifuged at $500 \times \mathrm{g}$ for $30 \mathrm{~min}$ at room temperature. The interface containing splenocytes was then removed and suspended in RPMI 1640. Splenocytes and thymocytes were then centrifuged at $300 \times \mathrm{g}$ for 10 min and cell pellets were resuspended in RPMI 1640 supplemented with $10 \%$ fetal bovine serum and $100 \mathrm{U} / \mathrm{ml}$ penicillin-streptomycin. Cells were treated with $0.5 \mu \mathrm{M}$ staurosporine or $50 \mu \mathrm{M}$ etoposide at a density of $2.0 \times 10^{6}$ cells $/ \mathrm{ml}$.

\section{Assessment of Cell Viability}

Cell viability was measured by retention and deesterification of calcein AM (40). For calcein, AM retention assay culture media in 96-well plates were replaced with $5 \mu \mathrm{M}$ calcein AM (Molecular Probes, Eugene, OR, USA) in Locke's buffer containing $154 \mathrm{mM} \mathrm{NaCl}, 5.6 \mathrm{mM} \mathrm{KCl}, 3.6 \mathrm{mM} \mathrm{NaHCO}$, $2.3 \mathrm{mM} \mathrm{CaCl}_{2}, 1.2 \mathrm{mM} \mathrm{MgCl} 2,5.6 \mathrm{mM}$ glucose, and $5 \mathrm{mM}$ HEPES, $\mathrm{pH}$ 7.4. After incubation at $37^{\circ} \mathrm{C}$ for $30 \mathrm{~min}$, fluorescence was measured using a CytoFluor II fluorometer (PerSeptive Biosystems, Framingham, MA, USA) at $485 \mathrm{~nm}$ excitation and $560 \mathrm{~nm}$ emission wavelengths.

\section{Analysis of DNA Fragmentation}

At the designated time periods after injury, animals were decapitated under sodium pentobarbital anesthesia, and the brains were removed rapidly and dissected. Sham operated (control) animals received anesthesia and surgery but were not subjected to trauma. Tissue samples were frozen on dry ice and kept at $-80^{\circ} \mathrm{C}$. Apoptotic DNA was isolated and labeled as previously described (41), with minor modifications. In brief, genomic DNA was extracted from control or injured cortex; 50-100 mg of tissue was lysed in $0.5 \mathrm{ml}$ of $7 \mathrm{M}$ guanidine hydrochloride and centrifuged at $10,000 \times \mathrm{g}$ for $15 \mathrm{~min}$. Supernatants were mixed with $1 \mathrm{ml}$ of Wizard Maxipreps Resin (Promega, Madison, WI, USA), and the suspension was drawn by vacuum through Wizard Midicolumns (Promega). Columns were washed with $3 \mathrm{ml}$ of washing solution and dried by centrifugation over a microcentrifuge tube at $10,000 \times \mathrm{g}$ for 2 min. DNA was eluted with $50 \mu \mathrm{l}$ of $\mathrm{H}_{2} \mathrm{O}$. Residual RNA was removed by incubation with $1 \mu \mathrm{g}$ of RNase A at $37^{\circ} \mathrm{C}$ for $30 \mathrm{~min}$. DNA was added to each $20 \mu \mathrm{l}$ of labeling mixture, which contained $10 \mathrm{mM}$ Tris-HCl, pH 9.0, $50 \mathrm{mM} \mathrm{KCl,} \mathrm{0.1 \%} \mathrm{Triton}$
$\mathrm{X}-100,10 \mathrm{mM} \mathrm{MgCl}_{2}, 2 \mu \mathrm{Ci}\left[\alpha-{ }^{32} \mathrm{P}\right] \mathrm{dATP}(3000$ $\mathrm{Ci} / \mathrm{mmol}$; Amersham, Arlington Heights, IL), and I U Taq DNA polymerase. Reactions were incubated at $72^{\circ} \mathrm{C}$ for $20 \mathrm{~min}$ and terminated by the addition of gel loading buffer. Samples were loaded onto a $1.5 \%$ agarose gel in Tris-Borate-EDTA running buffer and electrophoresed at $4 \mathrm{~V} / \mathrm{cm}$. Labeled DNA fragments were visualized by autoradiography of the dried gel.

\section{In Vitro DNA Fragmentation Assay}

Sham operated and injured rat cortex were homogenized in a Dounce homogenizer in $10 \mathrm{mM}$ HEPES/KOH, pH 7.2, 2 mM EDTA, 0.1\% CHAPS, $5 \mathrm{mM}$ dithiothreitol, $1 \mathrm{mM}$ phenylmethylsulphonyl fluoride, $10 \mu \mathrm{g} / \mathrm{ml}$ pepstatin A, $20 \mu \mathrm{g} / \mathrm{ml}$ leupeptin, and $10 \mu \mathrm{g} / \mathrm{ml}$ aprotinin (42). Homogenates were centrifuged at $13,000 \times \mathrm{g}$ for $30 \mathrm{~min}$. Supernatants were transferred to new tubes and stored at $-80^{\circ} \mathrm{C}$ until used. Protein concentration was estimated by the Bradford method (Bio-Rad, Hercules, CA, USA) according to recommendations by the manufacturer. $\mathrm{Nu}$ clei were prepared from rat cerebellum (43). In brief, minced tissue was homogenized in the buffer ([in mM] 15 PIPES-NaOH, pH 7.4, $80 \mathrm{KCl}, 15 \mathrm{NaCl}$, 5 EDTA, 1 DTT, 0.5 spermidine, 0.2 spermine, and l PMSF) containing $250 \mathrm{mM}$ sucrose in a Dounce homogenizer. An equal volume of the buffer containing 2.3 M sucrose was added and mixed. Then homogenates were layered over $10 \mathrm{ml}$ of the buffer containing 2.3 M sucrose in a Beckman SW28 centrifuge tube and centrifuged at $22,000 \mathrm{rpm}$ for $90 \mathrm{~min}$ at $4^{\circ} \mathrm{C}$. The pellet was resuspended in homogenization buffer containing $50 \%$ glycerol at a concentration of 3-7 $\times$ $10^{7}$ nuclei $/ \mathrm{ml}$ and stored at $-80^{\circ} \mathrm{C}(44)$. The reaction mixtures contained (in $\mathrm{mM}$ ) 10 HEPES, $\mathrm{pH}$ 7.0, $50 \mathrm{NaCl}, 3 \mathrm{MgCl}_{2}, 5$ EGTA, 1 DTT, 3 ATP, and 10 creatinine phosphate, with $50 \mu \mathrm{g} / \mathrm{ml}$ creatinine kinase, various amounts of the tissue extracts, and $5 \times 10^{5} \mathrm{nu}-$ clei in a final volume of $60 \mu \mathrm{l}$. The mixtures were incubated at $37^{\circ} \mathrm{C}$ for various periods. DNA from nuclei was isolated as described by Eldadah et al. (41). Nuclei were lysed with $300 \mu \mathrm{l}$ of $7 \mathrm{M}$ guanidine hydrochloride; lysates were mixed with $1 \mathrm{ml}$ of Wizard Minipreps DNA Purification Resin (Promega) and drawn by vacuum through a Wizard Midicolumn (Promega). The column was washed with $3 \mathrm{ml}$ of washing solution and dried by centrifugation over a microfuge tube at $10,000 \times \mathrm{g}$ for $2 \mathrm{~min}$. To elute the DNA, we added $50 \mu \mathrm{l}$ of Tris-EDTA buffer, pH 8.0, followed by centrifugation over a new microfuge tube. Residual RNA was removed by the addition of $1 \mu \mathrm{g}$ of RNase A and incubated at $37^{\circ} \mathrm{C}$ for $30 \mathrm{~min}$. DNA was analyzed by gel electrophoresis with $1.5 \%$ agarose in the presence of $0.5 \mu \mathrm{g} / \mathrm{ml}$ ethidium bromide.

\section{Immunoblot Analysis}

Cells were harvested, washed once with ice-cold PBS, and lysed on ice in a solution containing $50 \mathrm{mM}$ Tris-HCl (pH 7.5), $150 \mathrm{mM} \mathrm{NaCl}, 1 \mathrm{mM}$ EGTA, $1 \mathrm{mM}$ phenylmethylsulfonyl fluoride, $0.5 \%$ 
NP-40, $0.25 \%$ sodium deoxycholate, leupeptin $(5 \mu \mathrm{g} / \mathrm{ml})$, and aprotinin $(5 \mu \mathrm{g} / \mathrm{ml})$. After removal of cell debris by centrifugation, the protein concentration of the cell lysate was determined with the BioRad protein assay reagent. A portion of the lysate (30 $\mu \mathrm{g}$ of protein) was then fractionated by SDSpolyacrylamide gel electrophoresis (PAGE) through a $4-20 \%$ gradient gel, and the separated proteins were transferred to a nitrocellulose filter. The filter was stained with Ponceau $S$ to confirm equal loading and transfer of samples, and was then probed with specific antibodies. Immune complexes were detected with appropriate secondary antibodies and chemiluminescence reagents (Pierce, Rockford, IL, USA). Antibodies to DFF40 were obtained from Biovision; Palo Alto, CA, USA, antibodies to DFF45 were kindly provided by Dr. Xiaodong Wang.

\section{Results}

\section{DFF45 Is Essential for Expression of DFF40} in Mouse Brain

A role for DFF45 as a specific chaperone for DFF40 has been demonstrated in a number of in vitro experiments, as well as in bacterial expression and transfection studies. However, to our knowledge, this function of DFF45 has not been examined in vivo. To investigate whether DFF45 is essential for expression of DFF40 protein in vivo, we estimated levels of expression for the latter in brain cortex from wild-type and DFF45 knockout mice using Western blot analysis. Staining of protein samples from mouse brain cortex with DFF45-specific antibodies confirmed expression of DFF45 in wild-type animals, whereas it was not detected in samples from DFF45 knockout mice (Fig. 1). Staining of the samples with DFF40-specific antibodies demonstrated that DFF40 protein expression was barely detected in DFF45 knockout mice brain, in contrast to its abundant expression in wild-type mouse brain samples (Fig. 1).

\section{Internucleosomal DNA Fragmentation in Brain Cortex of DFF45 Knockout Mice}

Oligonucleosomal DNA fragmentation in cortex of mouse brain subjected to experimental TBI was

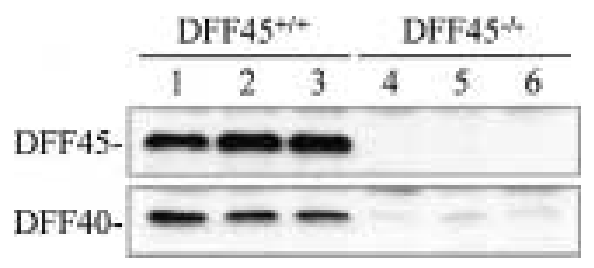

Fig. 1. Expression of DFF45 and DFF40 proteins in brain cortex tissue from three wild-type (lanes 1-3) and three DFF45 knockout mice (lanes 4-6) was monitored by immunoblot analysis as described in Material and Methods. DFF45 is absent and DFF40 protein is markedly reduced in brain cortex from the knockout mice.

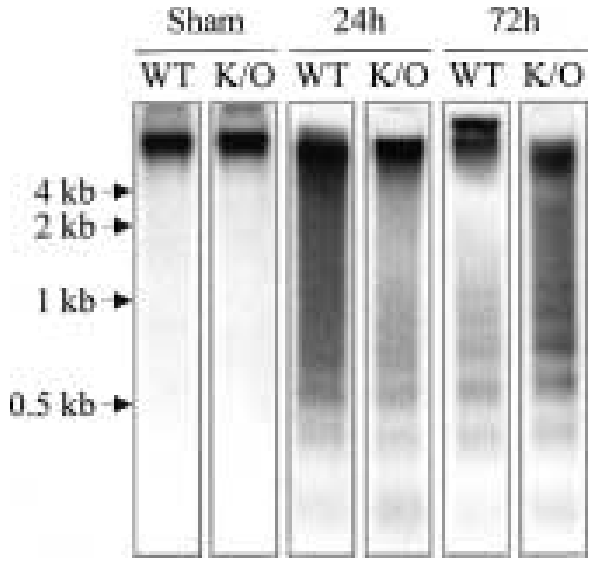

Fig. 2. TBI induces DNA fragmentation in brain cortex of DFF45 knockout mice. Total DNA was isolated from brain cortex of wild-type (WT) or DFF45 knockout mice (K/O) at indicated times after TBI. One microgram of DNA from each sample was labeled with $\left[\alpha{ }^{32} \mathrm{P}\right]$ dATP, using Taq DNA polymerase, and analyzed in $1.2 \%$ agarose gel. Dried gel was exposed with $\mathrm{x}$-ray film and photographed. Data are representative of four separate experiments with similar results.

examined by gel electrophoresis. Analysis of labeled DNA isolated from cortex of wild-type and DFF45 knockout mice demonstrated its fragmentation in affected areas (Fig. 2). DNA fragmentation from samples of injured but not from sham operated cortex was detected at 24 and $72 \mathrm{hr}$ after trauma. The extent of DNA degradation in wild-type mouse cortex appeared higher at 24 rather than $72 \mathrm{hr}$ after TBI, whereas, in DFF45 knockouts, this process was somewhat delayed, although it should be noted that this method of DNA fragmentation detection is not quantitative.

Deletion of DFF45 Gene Does Not Alter Neurologic Recovery or Injury Volume After TBI

The number of footfaults was markedly increased in both wild-type and DFF $45^{-1-}$ animals, with no significant differences observed between the groups before injury or at any time point after trauma (Fig. 3A). The effect of CCI on place learning in the Morris Water Maze task was analyzed by comparing the daily mean latency $( \pm S E M)$ to goal location over the four trials for each group. No significant differences were found between the groups from days 14 to day 17 (Fig. 3B). Moreover, on the initial trials there were no significant differences between injured and naive mice $(70.4 \pm 4.0$ versus $67.1 \pm 4.2$ for knockouts; $58.9 \pm 6.9$ versus $69.3 \pm 6.1$ for wild type), consistent with previous findings in this model comparing sham injured and brain injured mice $(34,35)$. Examination of working memory, performed on days 21-23, showed no significant differences between the groups for any day, although the latencies were consistently longer in the knockout animals (Fig. 3C). Lesion volume measurements, using high field MRI, also showed no significant 
A
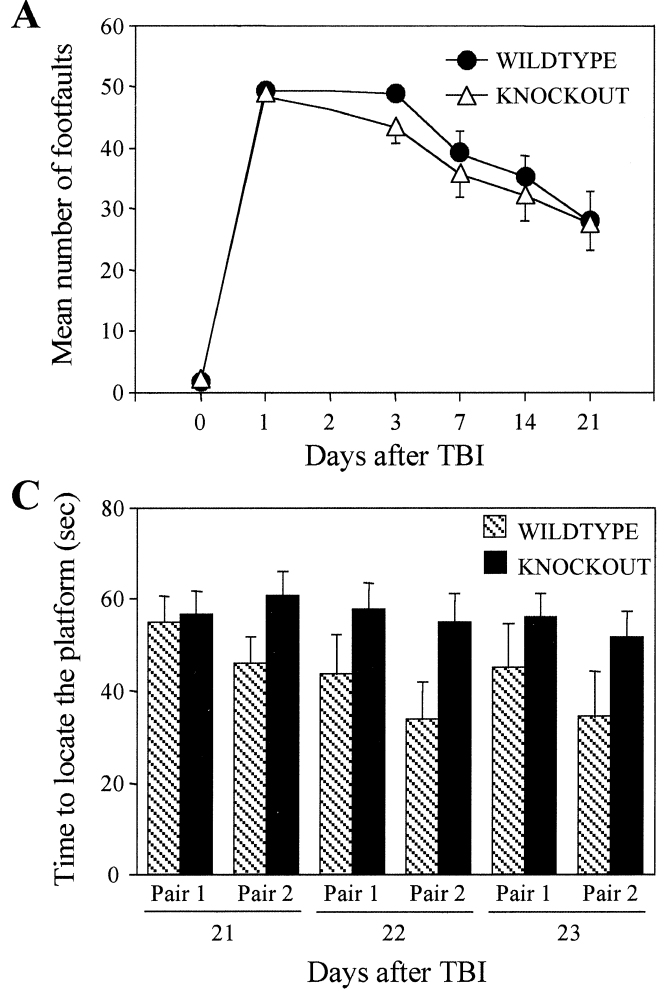

differences between groups, although there were trends toward larger lesion volumes in DFF45 knockout animals as compared to wild-type controls (Fig. 4).

DNA Fragmentation During Apoptosis and Cell Death Induced in Cultured Primary Cortical Neurons From Wild-Type and DFF45 Knockout Mice

To verify further a role of DFF40 in DNA fragmentation during neuronal apoptosis, we used primary

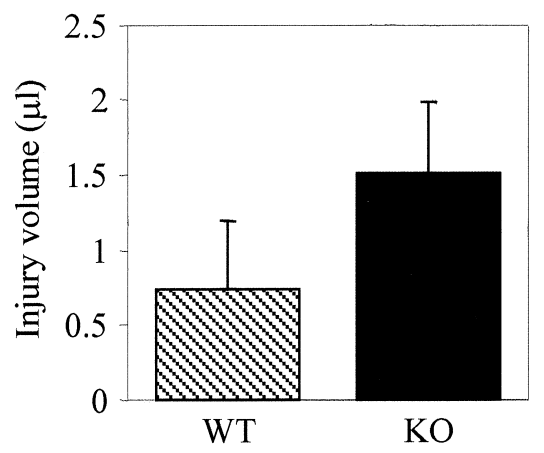

Fig. 4. Deletion of DFF45 gene does not alter lesion volume after TBI. The graph of lesion volume versus genotype shows that although the DFF45 knockout animals had a slightly larger lesion on average then the wild-type strain, this was not a statistically significant difference. Average injury volume for each group $( \pm$ SEM in $\bullet 1)$ was calculated and a onetailed $t$ test performed to determine significance of reduction in injured tissue in DFF45 knockout mice versus wild type;

$n=11$ for the wild-type group, $n=17$ for the knockout group.

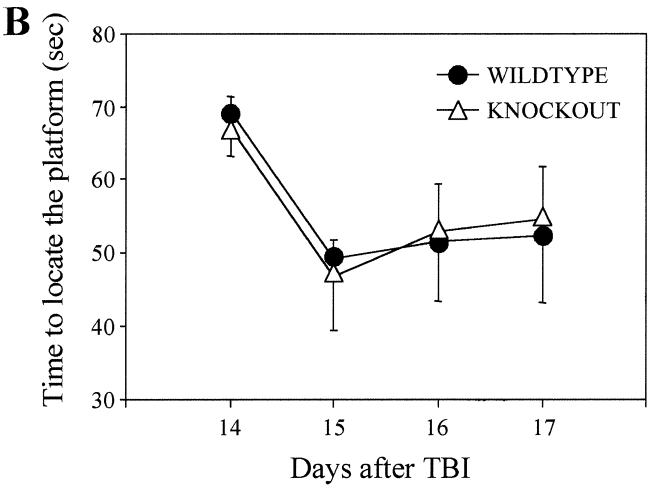

Fig. 3. Deletion of DFF45 gene does not alter neurologic recovery after TBI. (A) Performance of wild-type and DFF45 knockout mice in a beam-walking task measuring fine motor coordination. Results are expressed as mean \pm SEM number of contralateral hindlimb footfaults (maximum 50) per group. (B) Latency to find the hidden platform in a version of the Morris water maze. Results are expressed as daily means \pm SEM for each group over 4 trials. (C) Mean difference in latency $( \pm$ SEM) to locate the hidden platform between the first and second of the trial pairs in a working memory version of the Morris water maze, conducted at days 21, 22, and 23; $n=10$ for the wild-type group, $n=20$ for the knockout group.

cultures of cortical neurons from wild-type and knockout mice. Neurons in culture were treated with etoposide or staurosporine, established inducers of neuronal apoptosis. Agarose gel electrophoretic analysis of DNA integrity, performed after $24 \mathrm{hr}$ of treatment, demonstrated that both drugs caused DNA laddering in wild-type cells (Fig. 5A). In neurons from DFF45 knockout mice, staurosporine failed to induce DNA fragmentation after 24-hr incubation, whereas treatment with etoposide resulted in low levels of DNA laddering. When the incubation time with etoposide was increased from 24 to $48 \mathrm{hr}$, DNA fragmentation in DFF45 knockout neurons became prominent, while it was still not detected in knockout cultures treated with staurosporine. In contrast to neurons, spleen cells isolated from the knockout mice and exposed to etoposide or staurosporine did not develop DNA laddering even after $48 \mathrm{hr}$ of treatment, whereas wild-type splenocytes underwent extensive DNA fragmentation. Similar differences in DNA fragmentation were also observed in primary thymocytes isolated from wild-type or knockout mice after treatment with etoposide (Fig. 5B).

Viability of primary neurons was assayed by measuring calcein AM fluorescence. In accord with the difference in the extent of DNA fragmentation, a significant difference in cell viability was observed between wild-type and DFF45 knockout neurons after 24-hr treatment with etoposide or staurosporine (Fig. 5C). When the treatment time was increased to $48 \mathrm{hr}$, cell viability in both knockout and wild-type cultures decreased to a similar level 
A
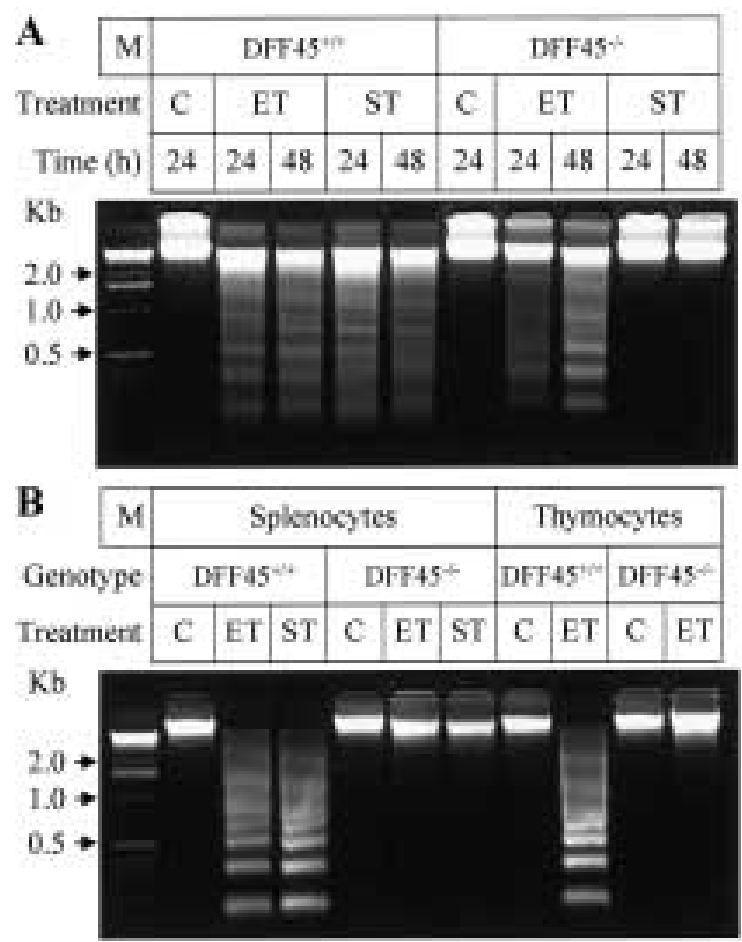

C
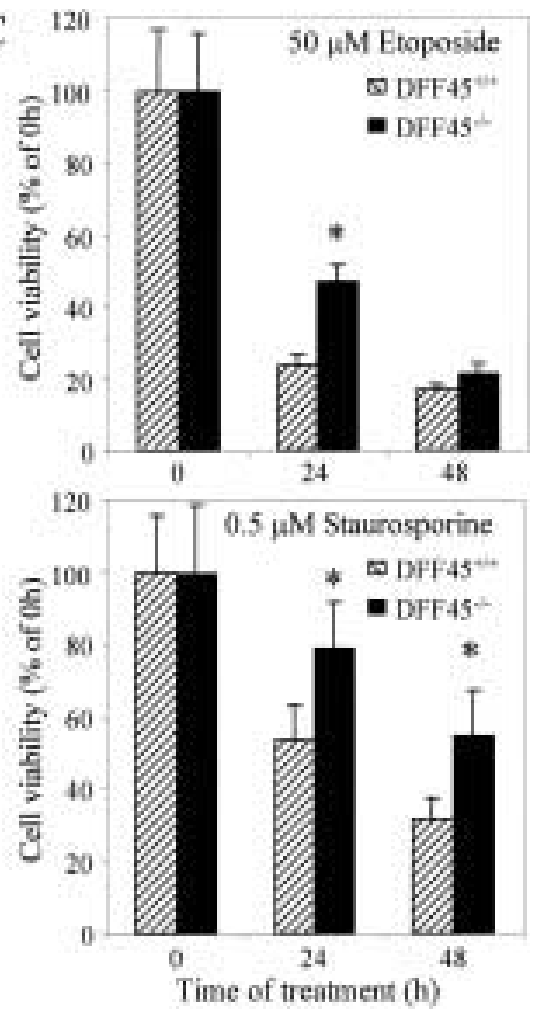

Fig. 5. Effects of DFF45 expression on DNA fragmentation in (A and B) and viability (C) of primary mouse cortical neurons (A and C), splenocytes, and thymocytes (B) exposed to etoposide (ET) or staurosporin (ST). Primary cells were incubated for 24 or $48 \mathrm{hr}$ in the absence or presence of $0.5 \mu \mathrm{M}$ staurosporine or $50 \bullet \mathrm{M}$ etoposide. The integrity of genomic DNA was then examined by electrophoresis through a $2 \%$ agarose gel, and cell viability was analyzed by measurement of calcein fluorescence. Data in (C) are expressed as a percentage of the value for control cells $(C)$ not exposed to inducers of apoptosis, and are means \pm SEM of six samples from an experiment that was repeated twice with similar results. ${ }^{*} p<.05$, compared with control, by ANOVA and Dunnett's test.

following etoposide treatment, whereas viability of the knockout neurons treated with staurosporine remained significantly higher than that of wild-type neurons under the same culture conditions (Fig. 5C).

\section{Reconstitution of Apoptosis In Vitro}

We have previously demonstrated that protein extracts isolated from traumatized rat cortex were able to induce the oligonucleosomal fragmentation of DNA in isolated nuclei (4). To further examine a role of DFF45 and DFF40 in apoptotic DNA laddering in rat brain, we employed such an in vitro apoptosis reconstitution system, using rat cerebellar nuclei or pCR2.1 plasmid DNA.

Agarose gel electrophoretic analysis indicated that the degree of DNA fragmentation induced in cerebellar nuclei (Fig. 6A) or plasmid DNA degradation (Fig. 6B) by extracts from injured cortex was consistent with the previously reported results (4): incubation of nuclei or pCR2.1 DNA with extracts from sham controls did not result in detectable degradation of DNA, whereas extracts from injured tissue isolated $24 \mathrm{hr}$ postinjury produced DNA cleavage. A greater degree of DNA degradation was observed with cortical extracts isolated 3 days after trauma.
We have previously reported that activation of a caspase-3-like protease(s) is necessary for TBIinduced DNA fragmentation in rat brain cortex,
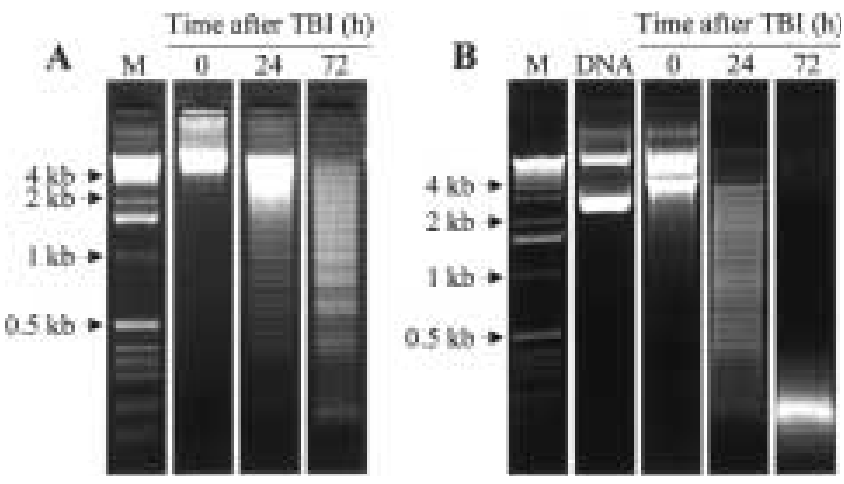

Fig. 6. DNA cleavage in isolated nuclei (A) and plasmid DNA (B) induced by cytosolic extracts from sham control $(0 \mathrm{hr})$ and injured rat cortex $(24$ and $72 \mathrm{hr})$. Cytosolic extracts from injured brain tissues were isolated at indicated times after TBI. Nuclei from rat normal cerebellum or pCR2.1 plasmid DNA were incubated with extracts, and DNA was analyzed by agarose gel electrophoresis, as described in Materials and Methods. Data are representative of tens of experiments with similar results. The standard DNA fragments (M) represent a 1-kb DNA ladder. 
because intracerebroventricular administration of $\mathrm{z}$ DEVD-fmk markedly reduced such DNA fragmentation in vivo and in vitro (4). To investigate a role of caspase-3-mediated DFF45 cleavage in DNA degradation during apoptosis in brain tissue, we examined the effect of active recombinant caspase- 3 on endonuclease activity in cytosolic extracts from sham control rat cortex. Increasing amounts of caspase-3 were incubated with cortical protein extracts. Integrity of DFF45 was monitored using specific anti-DFF45 antibodies. Western blot analysis demonstrated that the recombinant caspase- 3 cleaved DFF45 in the incubated extracts in a dose-dependent manner (Fig. 7A). However, DFF45 cleavage was not obvious in protein extracts from traumatized rat cortex isolated 3 days after TBI (Fig. 7A).

Extracts from sham operated cortex incubated with or without caspase- 3 and extracts from traumatized rat cortex isolated 3 days after trauma were incubated with rat cerebellar nuclei and DNA fragmentation was analyzed by agarose gel electrophoresis. Addition of caspase- 3 to control cortical extracts, leading to complete DFF45 cleavage, was not sufficient for induction of DNA laddering, whereas extracts from traumatized rat cortex produced DNA fragmentation without addition of the recombinant caspase (Fig. 7B).

\section{Cation Dependence of DNA Cleavage by Endonuclease Activity Induced by TBI}

To characterize ion dependence of TBI-induced endonuclease activity crude cytosolic extracts were isolated from injured rat cortex 3 days after trauma and tested for nuclease activity in a plasmid DNA cleavage assay. Cleavage of DNA by the extracts, readily observed in the reactions, was inhibited in the presence of $10 \mathrm{mM}$ EDTA (Fig. 8A), suggesting that endonuclease activity depended on $\mathrm{Ca}^{2+}$ and/or $\mathrm{Mg}^{2+}$ ions. DNA degradation was also inhibited by $20 \mu \mathrm{M}$ aurintricarboxylic acid, which inhibits the formation of protein-nucleic acid complexes and has been shown to inhibit apoptosis in a variety of experimental models $(45,46)$. In contrast, an inhibitor of $\mathrm{Ca}^{2+}$ - and $\mathrm{Mg}^{2+}$-dependent endonucleases, $2 \mathrm{mM}$ $\mathrm{ZnSO}_{4}(19,47-51)$, did not inhibit nuclease activity from injured brain.

In addition, the cation dependence of endonuclease activity induced by TBI was examined by adding $\mathrm{Ca}^{2+}, \mathrm{Mg}^{2+}$, or $\mathrm{Zn}^{2+}$ to the reaction mixtures with

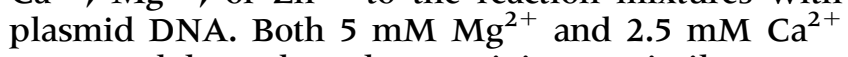
supported the endonuclease activity to a similar extent (Fig. 8B). However, the combination of these two cations did not produce a notable additive effect. Addition of $2 \mathrm{mM} \mathrm{Zn}^{2+}$ did not inhibit DNA degradation, as estimated in the presence of both $\mathrm{Ca}^{2+}$ and $\mathrm{Mg}^{2+}$.

\section{Discussion}

Previous studies have demonstrated that apoptosis plays an important pathophysiologic role in post-

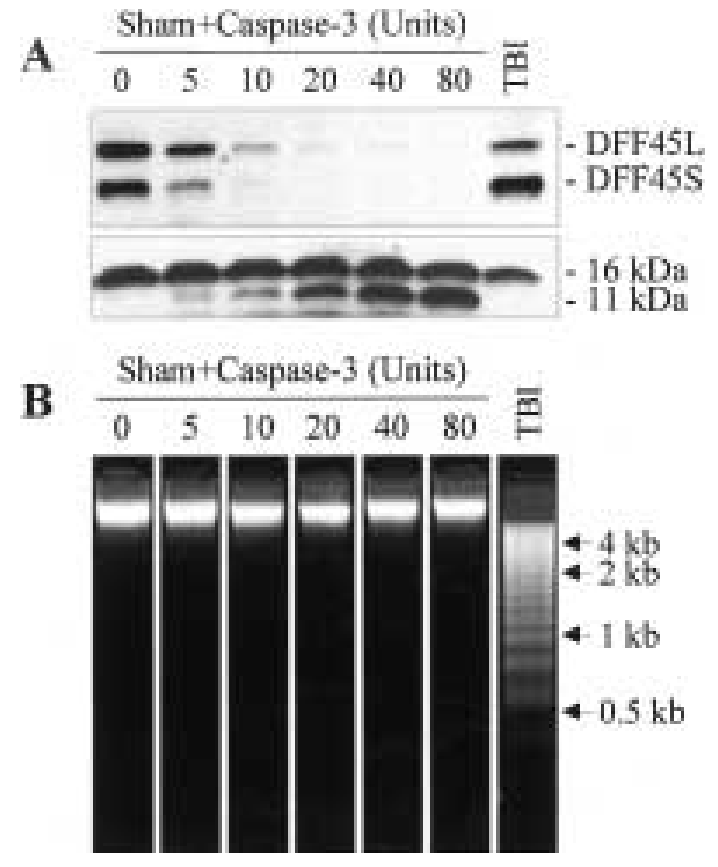

Fig. 7. A role for caspase-3-mediated DFF45 cleavage in DNA degradation in vitro. Protein extracts were isolated from sham operated or injured rat cortex isolated $72 \mathrm{hr}$ after TBI. Sham samples were treated with indicated amounts of the recombinant rat caspase- 3 for $1 \mathrm{hr}$ at $37^{\circ} \mathrm{C}$ in the extraction buffer (20 mM Hepes, pH7.4, 2 mM EDTA, $1.5 \mathrm{mM} \mathrm{MgCl}_{2}, 5 \mathrm{mM}$ DTT, and $0.1 \%$ CHAPS). (A) Half of each extract was then analyzed by Western blotting using anti-DFF45 antibodies that recognize two alternatively spliced forms of DFF45 (DFF45L and DFF45S), their cleavage products (11 kDa), and a nonspecific band (16 kDa). (B) The other half of the extracts were incubated with rat cerebellar nuclei as described in Materials and Methods. The DNA was then analyzed by electrophoresis through a $1.5 \%$ agarose gel and ethidium bromide staining. The result demonstrates that cleavage of DFF45 by caspase- 3 is not sufficient for DNA fragmentation induced by protein extracts from control rat brain cortex. Data are representative of four experiments with similar results.

traumatic neuronal cell loss and associated neurologic deficits after TBI $(1,4,7,35)$. Genome degradation appears to be an essential part of the apoptotic cascade, because it generally occurs at execution stages when cells are still viable. Inhibition of DNA fragmentation, in many instances, delays or blocks cell death $(19,49,51-54)$. Recent results demonstrated that overexpression of certain endonucleases in mammalian cells markedly exacerbates apoptotic cell death $(55,56)$. Nevertheless, a precise role for identified candidate apoptotic endonucleases in apoptosis remains controversial.

DFF40 is widely accepted as a key apoptotic endonuclease (8). However, recent reports indicate that in some cell types, activation of DFF40 by caspase- 3 is not sufficient for DNA fragmentation to proceed and that, in addition to DFF40/CAD-mediated DNA cleavage, other mechanisms and enzymes may be involved in the degradation of DNA during apoptosis (57-60). 

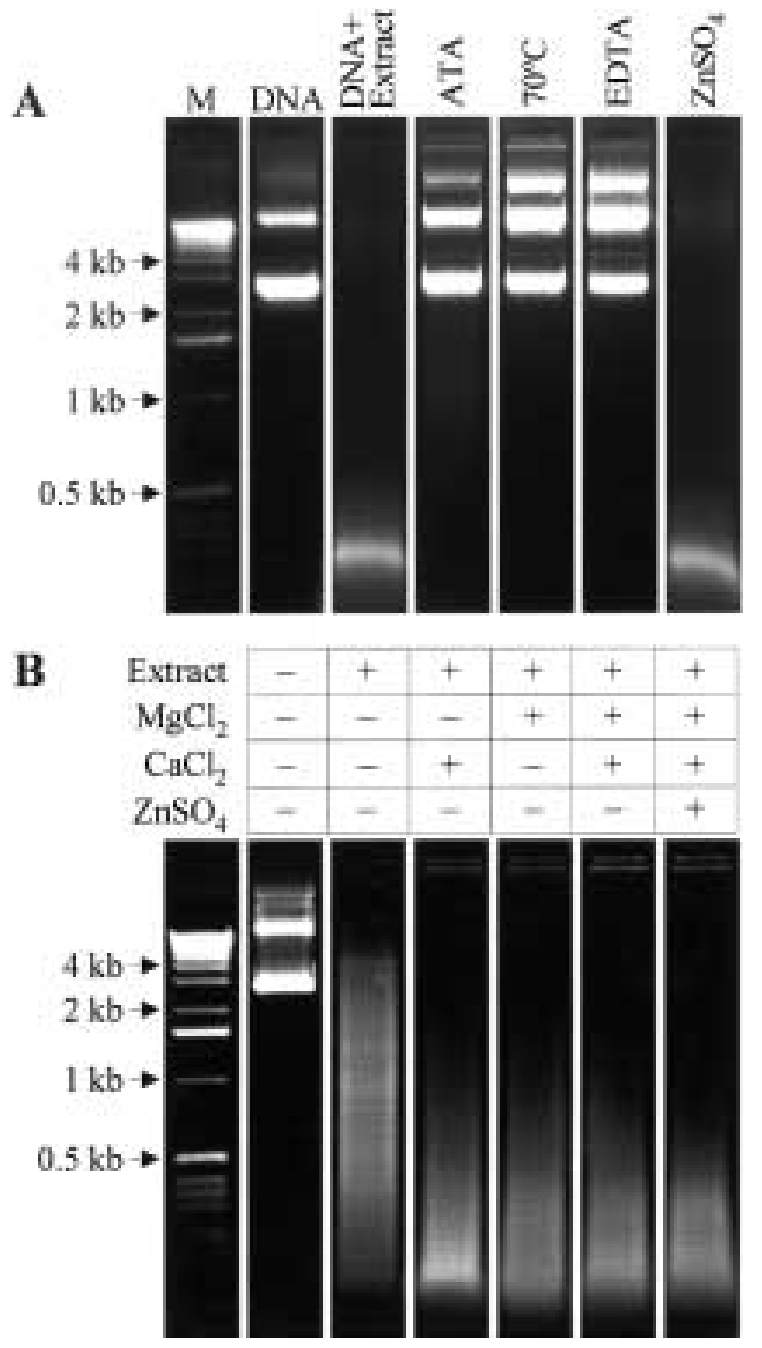

Fig. 8. Inhibition and cation dependence of TBI-induced endonuclease activity. (A) The nuclease activity in cytosolic extracts $(0.5 \mathrm{mg} / \mathrm{ml}$ final concentration) from injured rat cortex isolated $72 \mathrm{hr}$ after TBI was assayed in the presence or in the absence of $20 \bullet \mathrm{M}$ aurintricarboxylic acid (ATA), 10 mM EDTA, $2 \mathrm{mM} \mathrm{ZnSO}_{4}$, or the protein extracts were preheated at $70^{\circ} \mathrm{C}$ for $15 \mathrm{~min}$ before the reaction. The reactions were carried for $1 \mathrm{hr}$ at $37^{\circ} \mathrm{C}$ with $2 \cdot \mathrm{g}$ of pCR2.1 plasmid DNA in the buffer consisting of $10 \mathrm{mM}$ Hepes (pH7.4), $50 \mathrm{mM} \mathrm{KCl}, 3 \mathrm{mM} \mathrm{MgCl}{ }_{2}$, $1 \mathrm{mM}$ EDTA, 1 mM EGTA, $1 \mathrm{mM}$ DTT, $3 \mathrm{mM}$ ATP, $10 \mathrm{mM}$ phosphocreatine, $50 \bullet \mathrm{g} / \mathrm{ml}$ creatine kinase, and $20 \%$ glycerol. The DNA was then analyzed by electrophoresis through a $1.5 \%$ agarose gel and ethidium bromide staining. (B) Cation dependence of TBI-induced endonuclease activity was assayed in the presence of either $5 \mathrm{mM} \mathrm{MgCl}_{2}, 5 \mathrm{mM} \mathrm{CaCl}_{2}$, or $2 \mathrm{mM} \mathrm{ZnSO}_{4}$. The reactions were carried and DNA was analyzed as described for (A). This results show that the endonuclease activity induced in rat brain cortex following TBI depends on the presence of $\mathrm{Mg}^{2+}$ and $\mathrm{Ca}^{2+}$, but is not inhibited by $\mathrm{Zn}^{2+}$. Data are representative of three experiments with similar results.

To address the potential role of DFF40 and DFF45 in TBI-induced apoptotic DNA degradation, we utilized DFF45 knockout mice, which lack DFF40 nuclease activity (28). In this study, we examined expression of DFF40 protein directly in brain tissue from wild-type and DFF45 mutant mice. Western blot analysis demonstrated that expression of DFF40 is greatly reduced in DFF45 knockout animals. This observation strongly supports a role of DFF45 as a molecular chaperone for DFF40 protein expression in vivo.

To investigate a role for DFF40 in TBI-induced DNA fragmentation in brain cortex, we examined the extent of DNA degradation in samples from wild-type and DFF45 knockout mice. Qualitative analysis of DNA fragmentation suggested that this process was delayed in knockouts. This observation was supported by the experiments with primary cortical neuronal cultures, which also showed delayed DNA degradation in neurons from DFF45 knockouts after treatment with etoposide, as compared to wild-type controls. However, treatment of cultured DFF45 knockout neurons with saturosporine failed to induce DNA laddering even after prolonged incubation time. These results indicate that although DFF40 may participate in apoptotic DNA degradation in neurons, other nucleases also are involved and may play a more predominant role in certain models of neuronal apoptosis. In contrast, DFF45 appears to be essential for apoptosis in nonneuronal cells, as shown here and by others $(28,33)$.

It has been recently reported that DFF45 mutant mouse brain exhibits higher than wild-type brain granule cell number in the hippocampal dentate gyrus region (61). Moreover, Slane et al. (61) observed modestly increased spatial learning as measured by path length and cumulative distance from target; however, there was no difference between DFF45 knockout and control mice in escape latency. In the present study, we examined TBI-induced deficits in learning and working memory in the DFF45 knockout and wild-type groups of mice. No significant differences between the groups were found with regard to latency to find the submerged platform, although latencies for the working memory task performed on days 21-23 were consistently longer in the knockout mice.

Proton density and T2-weighted MRI have previously been shown to be a reliable method of measuring cerebral edema following experimental brain injury $(37,62-64)$. In this study, we applied the MRI technique for measuring of the injured brain tissue volumes following TBI in DFF45 knockout and wildtype mice. No significant difference in lesion volumes was found between the groups, although there was a trend toward larger lesions in the DFF45 knockouts.

Prior to the release of DFF40 nuclease activity, DFF45 must be cleaved by caspase-3 (9). We have previously reported that activation of caspase- 3 is necessary for TBI-induced DNA fragmentation in rat brain cortex (4). In the present study, using an in vitro reconstitution system, we demonstrated that cleavage of DFF45 by caspase-3 is not sufficient for DNA fragmentation induced by protein extracts from rat brain cortex. These results are in accord with a previous report showing failure of caspase- 3 
to induce DNA-cleaving activity in protein extracts from mouse brain (60). The results also indicate that activation of enzymes other than caspase-3 and DFF40 may be essential for chromatin degradation during apoptosis in adult brain after TBI.

Alternative mechanisms of apoptotic DNA fragmentation may be inferred from earlier studies. For example, $\mathrm{Ca}^{2+}$ ionophores such as A23187 induce DNA cleavage and apoptosis in primary thymocytes in the absence of additional apoptotic stimuli (65). Furthermore, liver nuclei contain endonuclease activity able to catalyze oligonucleosomal fragmentation of DNA in the presence of $\mathrm{Ca}^{2+}$ and $\mathrm{Mg}^{2+}$ ions. Other reports concluded that chromatin-bound CMEs are responsible for oligonucleosomal DNA fragmentation in nuclei from liver, thymus, spleen, and lymph nodes (12). CMEs have been isolated from different mammalian cell types and tissues including brain $(18,66-68)$. Other investigators suggested a link between intracellular $\mathrm{Ca}^{2+}$ and induction of apoptosis by demonstrating an elevation of cytosolic $\mathrm{Ca}^{2+}$ following corticosteroid treatment of thymocytes (69). CME activity is increased by a variety of stimuli that induce apoptosis, and certain treatments that prevent apoptosis also attenuate the induction of CME activity $(70,71)$. A role for CMEs in apoptosis is further supported by studies showing that $\mathrm{Ca}^{2+}$ chelators and $\mathrm{Zn}^{2+}$ ions block DNA fragmentation $(19,49,51-53,72)$.

In the present study, we characterized the ion dependence of endonuclease activity induced in rat brain cortex following TBI. This activity depends on the presence of divalent cations such as $\mathrm{Mg}^{2+}$ and $\mathrm{Ca}^{2+}$, but is not inhibited by $\mathrm{Zn}^{2+}$. This ion dependence of our "cortical" endonucleases differs from that of both DFF40 and characterized CMEs (73-75). Taken together, our results suggest that distinct endonucleases may contribute to genome degradation caused by brain trauma. Finally, although greatly reduced, the expression of DFF40 protein is still detectable in the DFF45 knockout mice (Fig. 1); therefore, development of a DFF40 knockout animal model would be required to establish a precise role for this endonuclease in neuronal apoptosis following brain injury.

\section{Acknowledgments}

We thank Dr. Xiaodong Wang for providing with anti-DFF45 antibodies. We also thank Wei-Li Bao for assistance in rat fluid percussion brain trauma experiments.

This work was supported by grants from the Department of Defense (DAMD17-99-2-9007) and The National Institutes of Health (NS 36537 and NS 38941).

\section{References}

1. Rink A, Fung KM, Trojanowski JQ, Lee VM, Neugebauer E, McIntosh TK. (1995) Evidence of apoptotic cell death after experimental traumatic brain injury in the rat. Am. J. Pathol. 147: 1575-1583.

2. Linnik MD, Zobrist RH, Hatfield MD. (1993) Evidence supporting a role for programmed cell death in focal cerebral ischemia in rats. Stroke 24: 2002-2008; discussion 2008-2009.

3. Li Y, Chopp M, Jiang N, Yao F, Zaloga C. (1995) Temporal profile of in situ DNA fragmentation after transient middle cerebral artery occlusion in the rat. J. Cereb. Blood Flow Metab. 15: 389-397.

4. Yakovlev AG, Knoblach SM, Fan L, Fox GB, Goodnight R, Faden AI. (1997) Activation of CPP32-like caspases contributes to neuronal apoptosis and neurological dysfunction after traumatic brain injury. J. Neurosci. 17: 7415-7424.

5. Thornberry NA, Lazebnik Y. (1998) Caspases: enemies within. Science 281: 1312-1316.

6. Colicos MA, Dash PK. (1996) Apoptotic morphology of dentate gyrus granule cells following experimental cortical impact injury in rats: possible role in spatial memory deficits. Brain Res. 739: 120-131.

7. Clark RS, Kochanek PM, Dixon CE, et al. (1997) Early neuropathologic effects of mild or moderate hypoxemia after controlled cortical impact injury in rats. J. Neurotrauma 14: 179-189.

8. Enari M, Sakahira H, Yokoyama H, Okawa K, Iwamatsu A, Nagata S. (1998) A caspase-activated DNase that degrades DNA during apoptosis, and its inhibitor ICAD [see comments] [published erratum appears in Nature 1998 May 28;393(6683):396]. Nature 391: 43-50.

9. Sakahira H, Enari M, Nagata S. (1998) Cleavage of CAD inhibitor in CAD activation and DNA degradation during apoptosis [see comments]. Nature 391: 96-99.

10. Liu X, Zou H, Slaughter C, Wang X. (1997) DFF, a heterodimeric protein that functions downstream of caspase- 3 to trigger DNA fragmentation during apoptosis. Cell 89: $175-184$.

11. Urbano A, McCaffrey R, Foss F. (1998) Isolation and characterization of NUC70, a cytoplasmic, hematopoietic apoptotic endonuclease. J. Biol. Chem. 273: 34820-34827.

12. Cohen JJ, Duke RC. (1984) Glucocorticoid activation of a calcium-dependent endonuclease in thymocyte nuclei leads to cell death. J. Immunol. 132: 38-42.

13. Wyllie AH, Kerr JF, Currie AR. (1980) Cell death: the significance of apoptosis. Int. Rev. Cytol. 68: 251-306.

14. Barry MA, Eastman A. (1993) Identification of deoxyribonuclease II as an endonuclease involved in apoptosis. Arch. Biochem. Biophys. 300: 440-450.

15. Fraser MJ, Tynan SJ, Papaioannou A, Ireland CM, Pittman SM. (1996) Endo-exonuclease of human leukaemic cells: evidence for a role in apoptosis. J. Cell Sci. 109: 2343-2360.

16. Zhivotovsky B, Wade D, Nicotera P, Orrenius S. (1994) Role of nucleases in apoptosis. Int. Arch. Allergy Immunol. 105: 333-338.

17. Mogil RJ, Shi Y, Bissonnette RP, Bromley $\mathrm{P}$, Yamaguchi I, Green DR. (1994) Role of DNA fragmentation in T cell activation-induced apoptosis in vitro and in vivo. J. Immunol. 152: 1674-1683.

18. Ribeiro JM, Carson DA. (1993) $\left.\mathrm{Ca}^{2+} / \mathrm{Mg}^{(2+}\right)$-dependent endonuclease from human spleen: purification, properties, and role in apoptosis. Biochemistry 32: 9129-9136.

19. Giannakis C, Forbes IJ, Zalewski PD. (1991) $\left.\mathrm{Ca}^{2+} / \mathrm{Mg}^{\left({ }^{2+}\right.}\right)$ dependent nuclease: tissue distribution, relationship to inter-nucleosomal DNA fragmentation and inhibition by $\mathrm{Zn}^{2+}$. Biochem. Biophys. Res. Commun. 181: 915-920.

20. McCarty JS, Toh SY, Li P. (1999) Study of DFF45 in its role of chaperone and inhibitor: two independent inhibitory domains of DFF40 nuclease activity. Biochem. Biophys. Res. Commun. 264: 176-180.

21. Sakahira H, Iwamatsu A, Nagata S. (2000) Specific Chaperone-like activity of inhibitor of caspase-activated DNase for caspase-activated DNase. J. Biol. Chem. 275: 80918096.

22. Halenbeck R, MacDonald H, Roulston A, Chen TT, Conroy L, Williams LT. (1998) CPAN, a human nuclease regulated by the caspase-sensitive inhibitor DFF45. Curr. Biol. 8: 537-540. 
23. Liu X, Li P, Widlak P, et al. (1998) The 40-kDa subunit of DNA fragmentation factor induces DNA fragmentation and chromatin condensation during apoptosis. Proc. Natl Acad. Sci. USA 95: 8461-8466.

24. McIlroy D, Sakahira H, Talanian RV, Nagata S. (1999) Involvement of caspase 3-activated DNase in internucleosomal DNA cleavage induced by diverse apoptotic stimuli. Oncogene 18: $4401-4408$.

25. Mitamura S, Ikawa H, Mizuno N, Kaziro Y, Itoh H. (1998) Cytosolic nuclease activated by caspase- 3 and inhibited by DFF45. Biochem. Biophys. Res. Commun. 243: 480-484.

26. Tang D, Kidd VJ. (1998) Cleavage of DFF-45/ICAD by multiple caspases is essential for its function during apoptosis. $J$. Biol. Chem. 273: 28549-28552.

27. Wolf BB, Schuler M, Echeverri F, Green DR. (1999) Caspase-3 is the primary activator of apoptotic DNA fragmentation via DNA fragmentation factor-45/Inhibitor of caspase-activated DNase inactivation. J. Biol. Chem. 274: 30651-30656.

28. Zhang J, Wang X, Bove KE, Xu M. (1999) DNA fragmentation factor 45-deficient cells are more resistant to apoptosis and exhibit different dying morphology than wild-type control cells. J. Biol. Chem. 274: 37450-37454.

29. Pike BR, Zhao $X$, Newcomb JK, Posmantur RM, Wang KK, Hayes RL. (1998) Regional calpain and caspase-3 proteolysis of alpha-spectrin after traumatic brain injury. Neuroreport 9: 2437-2442.

30. Buki A, Okonkwo DO, Wang KK, Povlishock JT. (2000) Cytochrome c release and caspase activation in traumatic axonal injury. J. Neurosci. 20: 2825-2834.

31. Zhang C, Raghupathi R, Saatman KE, LaPlaca MC, McIntosh TK. (1999) Regional and temporal alterations in DNA fragmentation factor (DFF)-like proteins following experimental brain trauma in the rat. J. Neurochem. 73: 1650-1659.

32. McIntosh TK, Noble L, Andrews B, Faden AI. (1987) Traumatic brain injury in the rat: characterization of a midline fluid-percussion model. Cent. Nerv. Syst. Trauma 4: 119134.

33. Zhang J, Liu X, Scherer DC, van Kaer L, Wang X, Xu M. (1998) Resistance to DNA fragmentation and chromatin condensation in mice lacking the DNA fragmentation factor 45. Proc. Natl Acad. Sci. USA 95: 12480-12485.

34. Fox GB, Fan L, LeVasseur RA, Faden AI. (1998) Effect of traumatic brain injury on mouse spatial and nonspatial learning in the Barnes circular maze. J. Neurotrauma 15: 10371046.

35. Fox GB, Fan L, Levasseur RA, Faden AI. (1998) Sustained sensory/motor and cognitive deficits with neuronal apoptosis following controlled cortical impact brain injury in the mouse. J. Neurotrauma 15: 599-614.

36. Morris R. (1984) Developments of a water-maze procedure for studying spatial learning in the rat. J. Neurosci. Methods 11: 47-60.

37. Albensi BC, Knoblach SM, Chew BG, O'Reilly MP, Faden AI, Pekar JJ. (2000) Diffusion and high resolution MRI of traumatic brain injury in rats: time course and correlation with histology. Exp. Neurol. 162: 61-72.

38. Di Stefano G, Bachevalier J, Levin HS, Song JX, Scheibel RS, Fletcher JM. (2000) Volume of focal brain lesions and hippocampal formation in relation to memory function after closed head injury in children. J. Neurol. Neurosurg. Psychiatry 69: 210-216.

39. Elger B, Hornberger W, Schwarz M, Seega J. (1997) MRI study on delayed ancrod therapy of focal cerebral ischaemia in rats. Eur. J. Pharmacol. 336: 7-14.

40. Eldadah BA, Yakovlev AG, Faden AI. (1997) The role of CED-3-related cysteine proteases in apoptosis of cerebellar granule cells. J. Neurosci. 17: 6105-6113.

41. Eldadah BA, Yakovlev AG, Faden AI. (1996) A new approach for the electrophoretic detection of apoptosis. Nucleic Acids Res. 24: 4092-4093.

42. Nicholson DW, Ali A, Thornberry NA, et al. (1995) Identification and inhibition of the ICE/CED-3 protease necessary for mammalian apoptosis. Nature 376: 37-43.
43. Newmeyer DD, Wilson KL. (1991) Egg extracts for nuclear import and nuclear assembly reactions. Methods Cell Biol. 36: 607-634.

44. Enari M, Hase A, Nagata S. (1995) Apoptosis by a cytosolic extract from Fas-activated cells. Embo. J. 14: 5201-5208.

45. Andrew DJ, Hay AW, Evans SW. (1999) Aurintricarboxylic acid inhibits apoptosis and supports proliferation in a haemopoietic growth-factor dependent myeloid cell line. Immunopharmacology 41: 1-10.

46. Heiduschka P, Thanos S. (2000) Aurintricarboxylic acid promotes survival and regeneration of axotomised retinal ganglion cells in vivo. Neuropharmacology 39: 889-902.

47. Shiokawa D, Ohyama H, Yamada T, Takahashi K, Tanuma S. (1994) Identification of an endonuclease responsible for apoptosis in rat thymocytes. Eur. J. Biochem. 226: 23-30.

48. Shiokawa D, Tanuma S. (1998) Molecular cloning and expression of a cDNA encoding an apoptotic endonuclease DNase gamma. Biochem. J. 332: 713-720.

49. Khodarev NN, Ashwell JD. (1996) An inducible lymphocyte nuclear $\mathrm{Ca}^{2+} / \mathrm{Mg}\left({ }^{2+}\right)$-dependent endonuclease associated with apoptosis. J. Immunol. 156: 922-931.

50. Kimura C, Zhao QL, Kondo T, Amatsu M, Fujiwara Y. (1998) Mechanism of UV-induced apoptosis in human leukemia cells: roles of $\mathrm{Ca}^{2+} / \mathrm{Mg}\left({ }^{2+}\right)$-dependent endonuclease, caspase-3, and stress-activated protein kinases. Exp. Cell Res. 239: 411-422.

51. Matsushita K, Kitagawa K, Matsuyama T, et al. (1996) Effect of systemic zinc administration on delayed neuronal death in the gerbil hippocampus. Brain Res. 743: 362-365.

52. Cigola E, Kajstura J, Li B, Meggs LG, Anversa P. (1997) Angiotensin II activates programmed myocyte cell death in vitro. Exp. Cell Res. 231: 363-371.

53. Verhaegen S, McGowan AJ, Brophy AR, Fernandes RS, Cotter TG. (1995) Inhibition of apoptosis by antioxidants in the human HL-60 leukemia cell line. Biochem. Pharmacol. 50: $1021-1029$.

54. Zhivotovsky B, Nicotera P, Bellomo G, Hanson K, Orrenius S. (1993) $\mathrm{Ca}^{2+}$ and endonuclease activation in radiationinduced lymphoid cell death. Exp. Cell Res. 207: 163-170.

55. Los M, Neubuser D, Coy JF, Mozoluk M, Poustka A, SchulzeOsthoff K. (2000) Functional characterization of DNase X, a novel endonuclease expressed in muscle cells. Biochemistry 39: $7365-7373$.

56. Yakovlev AG, Wang G, Stoica BA, et al. (2000) A role of the $\mathrm{Ca}^{2+} / \mathrm{Mg}^{2+}$-dependent endonuclease in apoptosis and its inhibition by Poly (ADP-ribose) polymerase. J. Biol. Chem. 275: 21302-21308.

57. Adjei PN, Kaufmann SH, Leung WY, Mao F, Gores GJ. (1996) Selective induction of apoptosis in Hep 3B cells by topoisomerase I inhibitors: evidence for a protease-dependent pathway that does not activate cysteine protease P32 [published erratum appears in J. Clin. Invest. 1997 Aug 15; 100(4):951]. J. Clin. Invest. 98: 2588-2596.

58. Wright SC, Schellenberger U, Wang H, Kinder DH, Talhouk JW, Larrick JW. (1997) Activation of CPP32-like proteases is not sufficient to trigger apoptosis: inhibition of apoptosis by agents that suppress activation of AP24, but not CPP32-like activity. J. Exp. Med. 186: 1107-1117.

59. Wright SC, Schellenberger U, Ji L, Wang H, Larrick JW. (1997) Calmodulin-dependent protein kinase II mediates signal transduction in apoptosis. FASEB J. 11: 843-849.

60. Wohrl W, Hacker G. (1999) Extent and limitation of the control of nuclear apoptosis by DNA-fragmenting factor. Biochem. Biophys. Res. Commun. 254: 552-558.

61. Slane JM, Lee HS, Vorhees CV, Zhang J, Xu M. (2000) DNA fragmentation factor 45 deficient mice exhibit enhanced spatial learning and memory compared to wild-type control mice. Brain Res. 867: 70-79.

62. Assaf Y, Holokovsky A, Berman E, Shapira Y, Shohami E, Cohen Y. (1999) Diffusion and perfusion magnetic resonance imaging following closed head injury in rats. J. Neurotrauma 16: 1165-1176.

63. Hockings PD, Middleton DA, Patel S, et al. (1995) Correlation between high-field T2-weighted MR imaging and 
histology of ischemic lesions in gerbil brain. J. Magn. Reson. Imaging 5: 437-442.

64. Loubinoux I, Volk A, Borredon J, et al. (1997) Spreading of vasogenic edema and cytotoxic edema assessed by quantitative diffusion and T2 magnetic resonance imaging. Stroke 28: 419-426; discussion 426-417.

65. Wyllie AH, Morris RG, Smith AL, Dunlop D. (1984) Chromatin cleavage in apoptosis: association with condensed chromatin morphology and dependence on macromolecular synthesis. J. Pathol. 142: 67-77.

66. Ishida R, Akiyoshi H, Takahashi T. (1974) Isolation and purification of calcium and magnesium dependent endonuclease from rat liver nuclei. Biochem. Biophys. Res. Commun. 56: 703-710.

67. Nikonova LV, Zotova RN, Umanskii SR. (1989) [Isolation of $\mathrm{Ca}^{2+}, \mathrm{Mg}^{2+}$-dependent nuclease from calf thymus chromatin]. Biokhimiia 54: 1709-1718.

68. Wyllie AH, Arends MJ, Morris RG, Walker SW, Evan G. (1992) The apoptosis endonuclease and its regulation. Semin. Immunol. 4: 389-397.
69. McConkey DJ, Hartzell P, Nicotera P, Orrenius S. (1989) Calcium-activated DNA fragmentation kills immature thymocytes. FASEB J. 3: 1843-1849.

70. Batistatou A, Greene LA. (1993) Internucleosomal DNA cleavage and neuronal cell survival/death. J. Cell Biol. 122: 523532.

71. Csernansky CA, Canzoniero LM, Sensi SL, Yu SP, Choi DW. (1994) Delayed application of aurintricarboxylic acid reduces glutamate-induced cortical neuronal injury. J. Neurosci. Res. 38: 101-108.

72. Bhattacharya R, Lakshmana Rao PV. (1997) Cyanide induced DNA fragmentation in mammalian cell cultures. Toxicology 123: 207-215.

73. Nagata S. (2000) Apoptotic DNA fragmentation. Exp. Cell Res. 256: $12-18$.

74. Robertson JD, Orrenius S, Zhivotovsky B. (2000) Review: nuclear events in apoptosis. J. Struct. Biol. 129: 346-358.

75. McConkey DJ. (1996) The role of calcium in the regulation of apoptosis. Scanning Microsc. 10: 777-793. 